Western Washington University Western CEDAR

\title{
Throwaway Youth: The Sociocultural Location of Resistance to Schooling
}

Tracey Pyscher

Western Washington University, tracey.pyscher@wwu.edu

Brian D. Lozenski

Follow this and additional works at: https://cedar.wwu.edu/woodring_dei

Part of the Education Commons

\section{Recommended Citation}

Tracey Pyscher \& Brian D. Lozenski (2014) Throwaway Youth: The Sociocultural Location of Resistance to Schooling, Equity \& Excellence in Education, 47:4, 531-545, DOI: 10.1080/10665684.2014.958964

This Article is brought to you for free and open access by the Woodring College of Education at Western CEDAR. It has been accepted for inclusion in Woodring Scholarship on Diversity, Equity, Inclusion by an authorized administrator of Western CEDAR. For more information, please contact westerncedar@wwu.edu. 


\title{
Throwaway Youth: The Sociocultural Location of Resistance to Schooling
}

\author{
Tracey Pyscher \\ University of Minnesota \\ Brian D. Lozenski \\ Metropolitan State University
}

\begin{abstract}
This article illuminates the ways in which resistant youth challenge attempts toward cultural homogenization within public school systems. We trace how youth from historical and lived traumatic experiences such as African American, Native American, and youth with histories of domestic violence, navigate the dominant narrative of pity and punishment in public schools. We argue that these resistive youth have been tagged with constructed identities as "broken youth." The article situates the practice of school discipline in terms of traditional and neoliberal agendas that seek to throw away noncompliant students and label them as deviant and/or disordered. Drawing from Bauman's (2009) conception of a world where vast numbers of human beings are increasingly seen as expendable and unworthy of a dignified existence, this article seeks to uncover how disciplinary and labeling practices become a vital part of the school-to-prison pipeline. We trace how deficit oriented discourses of historical and familial domestic violence help shape the often-unintentional violent discourses of pity and punishment towards resistant youth in public school settings.
\end{abstract}

"Educators, parents, and youth try to negotiate conditions of systematic miseducation and the scientism of high-stakes testing, while ideologies about merit, deservingness, and blame drip feed into the soul, tagging some bodies as worthy and others as damaged."

-Fine and Ruglis, 2009, pp. 20-21

Duncan-Andrade and Morrell (2008) open their text The Art of Critical Pedagogy with a presupposition that challenges the dominant national narrative of failing schools by saying that "urban schools are not failing; they are doing precisely what they are designed to do" (p. 10). The "what" that urban schools are doing so well is maintaining the social and economic hierarchy delimited by race, ethnicity, and gender. Generations of researchers have exposed the capacity of schools to reproduce the inequities of US society (Anyon, 1997; Bowles \& Gintis, 1976; Counts, 1932); as critical educators with over 20 years of combined experience teaching in urban schools, we witnessed the realities of their findings on a daily basis. We concur that urban schools are operating like well run factories attempting to produce compliant citizen-subjects who quietly 
take their place in the American social hierarchy. However, as with any form of production, there are "defective products." In schools, youth who resist homogenization in favor of maintaining cultural integrity (Carter, 2005) through resistive practices are labeled and treated as defective students to be thrown away, often leading to incarceration.

Our language is intentionally provocative in order to expose the realities of what is happening to marginalized youth. The education systems we are critiquing work to destroy these youth through mechanisms such as the school-to-prison pipeline and to position them as human waste. By mobilizing deficit discourses in our language (e.g., parasitic metaphor), we illuminate the often coded words used to rationalize acts of disposal and containment of youth who do not fall in line with the logics of efficiency (e.g., taking their predetermined place in society). We recognize that our use of deficit metaphors entails risk due to misappropriation, yet that very risk holds the potential for realizing our goal of reframing the dominant discourse. In this article we name the devastating ways youth are situated as unworthy amidst violent circumstances. Our intention is to open possibilities for rethinking discourse and practice regarding resistive youth.

This article addresses the theoretical issue of how to characterize the rebellious acts of marginalized youth in public school settings as acts of resistance rather than acts of behavioral deficit (Carter, 2005; Fordham \& Ogbu, 1986; Willis, 1977). We draw from foundational youth resistance literature (Giroux, 2001; Tuck \& Yang, 2014; Sleeter, 1987) and try to extend the field through a unique reframing of historical, cultural, and medical perspectives of youth resistance. The dominant research related to youth with histories of domestic violence is almost entirely grounded in medical, historical, and psychological deficit perspectives (Snyder \& Mitchell, 2006). Subsequently, common educational practices, like Emotionally Behaviorally Disordered (EBD) labeling, often further isolate an already marginalized population. Although the stated intent of these fields of research is to support youth with traumatic histories, deficit discourses and consequential practices (e.g., suspensions) can lead to interactions that are counterproductive in schooling situations. Furthermore, there is limited critical sociocultural research that seeks to understand how youth with histories of domestic violence navigate and construct their identities in public schools. Our purpose is to provide a methodological intervention through an asset-based critical sociocultural lens (Lewis, Enciso, \& Moje, 2007) that illustrates the lived and historical experiences of these youth. We merge the sociocultural theory of Bakhtin (1981) (i.e., carnival) with that of queer, feminist, mestiza scholar Anzaldúa (1987) (i.e., la facultad) in an effort to paint a picture of the transformative qualities of resistance.

We situate the educational experiences of African American and Native American communities in terms of historical long-term violence and trauma (Sotero, 2006) within the foundational youth resistance literature. The historical experiences of these racialized communities are then juxtaposed with youth who have lived histories or current experiences of domestic violence. We contend that resistant practices of traditionally marginalized youth in school amount to techniques for cultural survival in response to often-unintentionally violent practices of educators and school personnel that we describe as resistive ambivalence (Pyscher, 2012). These resistive practices help youth to mediate the abuses of power and the deficit discourses of pity and punishment (e.g., suspensions, special education labeling). At times, these two social locations (race and histories of domestic violence) entangle each other, while both share a continual and intimate relationship (and response) to social and cultural violence found in public school settings. We are not suggesting that the youth whose experience we foreground in this text (i.e., African American, Native American, youth from domestic violence) are the only youth who are positioned in these precarious ways 
by education systems, or that all youth from these populations experience schooling and practice resistance in similar ways. We recognize that Latin@, queer, and undocumented youth who come from poverty, among others, are often positioned in similar ways. Our purpose is to focus on specific racialized and marginalized groups to illustrate how the mechanisms of education systems perpetuate the production of throwaway youth.

One of the more insidious ways that race and childhood experiences of domestic violence intersect is in the exploding US prison population. According to Alexander (2012), there are more African American men in prison today than there were enslaved in 1850. Compounding this disgraceful reality is the percentage of prisoners who have histories of domestic violence. As a society, we do not openly discuss domestic violence and yet its reality is front and center for youth whose lives are deeply shaped by it. The prevalence of domestic violence is staggering. For instance, over $32.9 \%$ of women will have experienced physical violence by their intimate partner within their lifetime (Black, Basile, Breiding, Smith, Walters, Merrick, \& Stevens, 2011) and, every year, 3.3 million reports of child abuse, involving nearly 6 million children, are made in the US (Child Welfare Information Gateway, 2006). These youth make up the bulk of the American foster care system and constitute a majority of the youth who have come to be labeled as Emotionally and Behaviorally Disordered (EBD) (Administration for Children and Families, 2004). The empirical data on school success among these youth are equally troubling, for they often share unsuccessful schooling experiences with those who are socially and culturally marginalized in other ways, such as through raced and classed opportunity gaps. At best, the schooling landscape is bleak for many - if not most — of these youth. Compounding these challenges is that these students' experiences of domestic violence are mostly invisible in school settings, whereby their often-assigned identities (e.g., "at-risk" youth) are typically situated in deficit-ridden discourses emblematic of the school-to-prison pipeline. Not surprisingly, these same children are over-represented in other marginalized spaces, such as prostitution (Messina \& Grella, 2006). For Native American women who have engaged in prostitution, " $79 \%$ of the women had been sexually abused as children" (Minnesota Indian Women's Sexual Assault Coalition, 2009). The school-to-prison pipeline is solidified for "[c]hildren who experience child abuse and neglect [who] are $59 \%$ more likely to be arrested as a juvenile, $28 \%$ more likely to be arrested as an adult, and 30\% more likely to commit violent crime" (Child Welfare Information Gateway, 2006). In fact, Dewey (1997) found that over $73 \%$ of incarcerated women experienced some form of childhood domestic violence, highlighting the disturbing realization that domestic violence is a greater common denominator than race or poverty for US prisoners.

This narrative does not begin in our nation's penitentiaries-it begins in our nation's schools. The research uncovering the school-to-prison pipeline is undeniable (Kim, Losen, \& Hewitt, 2010), yet little is being done to sever the pipeline as school districts and judicial systems become further entangled. Our research is intended to shed light on the ways in which dominant, deficitoriented educational discourses of "at-risk," "damaged," and "emotionally and behaviorally disordered" youth and free market-based educational structures provide a logic to the procedural movement of targeted youth from classrooms to schooling warehouses, and eventually to prisons.

Our research arose from the need to illuminate how "throwaway" or "wasted" youth have been incorporated into the dominant narrative as parasites. The parasitic narrative ignores the systemic reproduction of "throwaway" youth for the purpose of legitimizing economic hierarchy and meritocracy. We contend that the construction of the "parasitic human" is a dialectic that both perpetuates and contradicts itself. Ultimately, these youth and their perceived "parasitic" ways 
"continually threaten to surface this hierarchy (class, race, violent practices in schooling) as a social fiction" (Snyder \& Mitchell, 2006, p. 57). The parasitic narrative does not work without the presupposition that there exists a healthy host. This article is meant to debunk the idea that public education is representative of a healthy host, therefore, students situated as "parasites" are not parasitic, but rather serve as barometers that measure the health of the host.

\section{THE AGENDA FOR THROWAWAY YOUTH: HISTORICAL AND REAL-TIME REALITIES}

Research exploring how African American and Native American youth navigate public schooling (Carter, 2005; Fletcher, 2008) has often argued that a significant subset of these youth, who typically don't prescribe to white middle class cultural and linguistic norms, resist the hegemonic norms inherent in schooling. Importantly, there is little to no research that illuminates the experiences of youth with histories of domestic violence as something other than disordered (Administration for Children and Families, 2004; Waitoller, Artiles, \& Cheney, 2010), yet we have come to see that racialized youth and youth whose lives have been socially and culturally constructed by experiences of domestic violence share a common cultural practice: resistance to mostly unintentiona ${ }^{1}$ violent/violating practices found in public schools. Situated in the dominant deficit discourses of trauma, we begin to see an emergent entangled relationship between African and Native American youth and youth whose lives grew of out the cultural and social location of domestic violence. For instance, their shared social and cultural locations are often constituted in public school classrooms for "emotionally behaviorally disordered" (EBD) youth. The literature is clear: A statistically vast majority of incarcerated and EBD youth are African American and other youth socially and culturally located by experiences of childhood familial violence (Dewey, 1997; Messina \& Grella, 2006).

Using a Foucauldian (1973) analysis, the cyclical relationship is clear. As we trace these entanglements we come to see a common pattern: Resistive youth that share historically racialized and/or lived experiences of domestic violence are often not only labeled as "disordered" through the deficit discourses of trauma, but are segregated and removed from public spaces in service to a greater purpose - the containment of resistive acts. This greater purpose is further situated in the neoliberal attempts to commodify students through mechanisms of homogenization and standardization that, in effect, create "disqualified" or "throwaway" students. Those who refuse to comply or assimilate to hegemonic norms are then warehoused in spaces of "disorder" (e.g., EBD classrooms, juvenile delinquency facilities).

As critical educators and sociocultural researchers with commitments to counter-hegemonic thought, we were unceremoniously called together to do this work. The joining of Native Americans, African Americans, and youth with histories of domestic violence became obvious to us as we began to sift through data, focusing on those youth most over-represented in high school dropout rates, school discipline referrals, EBD classrooms and, not coincidentally, in spaces of prostitution and imprisonment. To be clear, we are in no way attempting to essentialize nor conflate these populations, rather we want to make sense of the entanglement that already exists in some of the most violent/violating social spaces. Below we trace the differentiation and intersections of these groups so as to not oversimplify their histories. 
As with any analysis, it is imperative to historicize current narratives. In this case, we must uncover the history of the all too accepted narratives and the very creation of expendable youth in schools because these have not always existed. Expendable youth have developed over time, although in many ways they were manifested during the insidious inception of the US through settler colonialism (Tuck \& Yang, 2012). As critical researchers dedicated to a liberatory analysis, we want to be careful to heed Tuck's (2009) warning to resist describing oppressed Native and African communities as broken, or to engage in damage-centered analyses of marginalized communities. Rather, Tuck calls for an epistemological shift to a desire-based framework. Our belief is that by situating the resistive practices of Native American, African American, and youth with histories of domestic violence, within the context of a sociocultural mediation of historical and contemporary trauma, we embrace Tuck's notion of desire-based research.

At the same time, however, Carter (2005) warns researchers not to situate cultural practices as "primarily responses to exclusion, discrimination, and historical interracial tensions" (p. vii) because it also does a disservice to marginalized communities by devaluing their cultural practices as not having worth or agency in and of themselves. Describing cultural practices exclusively as a response also essentializes certain practices and creates monolithic cultural communities. Our use of critical sociocultural theory (Lewis, Enciso, \& Moje, 2007) attempts to resist the reproduction of this damaging research paradigm. What we put forward is an asset-based framework that acknowledges the historical and contemporary trauma inflicted upon marginalized communities, and situates its practices among repertoires (Gutierrez \& Rogoff, 2003) that predate colonization and enslavement and have enabled these communities to thrive amidst inhumane environments. That being said, our charge in this work is to name the continuing destructive practices that exist in schools, which continue to deprive and punish youth from these communities in an effort to maintain settler colonial social hierarchy through the technologies of patriarchy, capitalism, and white supremacy.

As Bauman (2009) paints a modern picture of a deteriorating world beholden to "liquid modernity" (p. 15), the feminist, Mestiza scholar, Gloria Anzaldúa (1987), provides some historical context to the intentional deterioration of Indigenous knowledges that has gone on for centuries. Here, "Western culture made 'objects' of things and people when it distanced itself from them, thereby losing 'touch' with them. This dichotomy is the root of all violence" (p. 59). Anzaldúa describes a Western world that seeks to separate the mind from the body from the spirit, which denies the worldview of Indigenous Americans who have embedded this way of being into their cultural practices for centuries. Although Europeans have come to dominate the Americas, Anzaldúa describes these practices as still existing in embodied and actionable ways among Indigenous peoples. Anzaldúa's depiction of la facultad, or "the capacity to see in surface phenomenon the meaning of deeper realities" (p. 60), is directly connected to our work, which socioculturally locates resistant youth as engaging in resistant and rebellious practices for the purpose of self-defense and survival amidst precarious circumstances (McKenzie, 2009). Anzaldúa (1987) writes, "those who do not feel psychologically or physically safe in the world are more apt to develop [la facultad]. Those who are pounced on the most have it the strongest ..." (p. 60). If we consider the youth who fit Anzaldúa's description- "the females, the homosexuals of all races, the darkskinned, the outcast, the persecuted, the marginalized, the foreign" (p. 60) - we begin to see the emergence of the very students who often develop resistant practices as necessary forms of agency. Students labeled EBD are literally "pushed out of the tribe" (Anzaldúa, 2004, p. 60) of mainstream (whitestream) classrooms for not conforming to the 
desires of their teachers for compliance within classrooms. These students often see the "deeper realities" of irrelevant pedagogy and curricula that seeks to subjugate them even further by ignoring their cultural knowledges that have been built from historical and lived realities. La facultad, for students who read and respond to their sociocultural experiences built from historical trauma or long-term familial violence, becomes a preventative bodily knowledge (Bourdieu, 1997) or a lived resistance (Pyscher, 2012) to impending physical, emotional, or psychical/spiritual dangers. Thus, when educators take up an authoritative stance/management of youth with these histories, they may be triggering la facultad. A quick glimpse of the historical uses of formalized education for Native American and African American youth illuminates the intergenerational trauma in the relationship between these communities and US schools.

Grande (2004) documents the historical realities of Native American education and equates the schooling of Native Americans to "a well-established weapon in the arsenal of American imperialism" (p. 11). Certainly the Native American boarding schools, which sought to "kill the Indian and save the man" (Pratt, 1973, p. 260), have produced, at best, an embodied skepticism, or, at worst, a fundamental distrust of US. education, within the intergenerational cultural knowledges of Indigenous peoples. Grande documents the historical trauma perpetrated against Indigenous youth in an effort to Anglicize an entire generation.

The process began with the (often forcible) removal of young children from their homes and communities and transporting them to a geographically and ideologically foreign place ... children were subject to English-only and Anglo-centric curricula ... forced labor and "patriotic" propaganda ... children were often undernourished and subjected to overcrowded living spaces. (2004, p. 14)

In the classrooms of today, despite efforts from numerous Indigenous educators (Grande, 2004), Native American youth continue to experience the remnants of attempts to Anglicize them, not through physical abuse and forced labor, but through modern Anglo-centric curricula that seeks to, at best, ignore, and, at worst, erase their historical and cultural selves.

Unlike Native Americans who were forcibly schooled for the purpose of cultural erasure, Africans Americans have had to engage in a perpetual struggle for access to education in the US, which ironically has sought similar outcomes with regard to cultural erasure. The battles African Americans have fought for the right to receive a quality education are well-documented (Anderson, 1988). The traumatic history of black education in the US has encompassed learning to read at the threat of imprisonment or death, de jure segregated and economically unequal schools, children being escorted to desegregated schools by the military for their physical protection, busing to racially isolated geographic areas, denigration of black language and communication styles, Eurocentric curricula, racialized tracking, and de facto segregation and overcrowded, under-resourced schools. As with Native American communities, African Americans have had to develop intergenerational cultural practices to mediate education systems' continued attempts to mis-educate (Woodson, 1933/1990) black children.

Today, the special education label of EBD is often attached to youth with histories of domestic violence who may not comply behaviorally in public schools. In many ways, these youths' narratives and assigned deficit identities are commonly silenced or are missing altogether in all fields of educational literature. The narratives are too wrapped in the discourses of brokenness that intersect with racialized and classed marginalizations. We trouble the common sense discourse that if one is shaped by domestic violence as a child/youth, then that same child needs to be "untraumatized" or "reordered." More recently, these deficit positionings have emerged through 
the language of "at-riskness" (Vadeboncoeur \& Luke, 2004) and is now entangled in the pity and deficient laden discourses of emotional behavioral disorders.

Bauman (2009) argues, "It is human design that conjures up disorder together with the vision of order, dirt together with the project of purity" (p. 19). The violent practices of public schools (McKenzie, 2009), such as tagging and labeling youth as EBD, dramatically impacts how youth are dealt with in this public space. The tagging process of disorder did not originate in schools or with teachers, but rather through greater authoritative bodies like that of the American Psychological Association (APA) and the industrial health care complex. The effect of these medicalized/deficit models of diagnoses is to attribute so-called biological deficits to youth, who are, in many cases, engaging in cultural forms of resistance to physically and psychologically threatening social environments. The deficit-medical diagnoses of youth can be likened to Roberts' (2011) notion of biological attributions of certain diseases (e.g., diabetes, cancer, heart disease) to racial groups when, in reality, they are the effects of unnatural, unequal, and unhealthy social conditions. As if the labeling of these youth as deficient is not damaging enough, if we begin to take into account the classed, raced, and domestic violence implications of the labeling process, what begins to take shape are the beginnings of these students' entry into a racial and socioeconomic undercaste (Alexander, 2012), as throwaway youth, which they are unlikely to escape.

Furthermore, the current realities of public schools, that are navigating the neoliberal acts of accountability and efficiency (Harvey, 2005) while sharing the dominant deficit discourses of trauma constructed by the fields of educational and pathological psychology, have setup a destructive force that collides with the need for warehoused spaces of disorder (e.g., EBD classrooms, prisons, ghettoes). In effect, this discourse silences its relationship to economic, racial, and domestic violence. As Bauman (2009) argues, these warehouses serve an important function in the production of what he calls "human waste," which "is an inevitable outcome of modernization, and an inseparable accompaniment of modernity. It is an inescapable side-effect of order-building" (p. 5). Not only are a significant number of Native Americans, AfricanAmericans, and youth with histories of domestic violence facing these realities of the age of accountability and efficiency, they are equally fending off the age-old discourses of pity and punishment that frame their resistive acts to social and cultural violence as something tied to their individualized "brokenness." We later explore the relationship between how youth positioned as "waste" and "parasites" in public schools enact resistive ambivalence (Pyscher, 2012) in response to these euphemized violent sociocultural discourses and practices.

\section{THE DISCOURSE OF THE “DISORDERED” OTHER: A PRODUCTIVE EUPHEMISM}

\section{From At-Riskness to Disorder}

The 1983 report, "A Nation at Risk," documenting a perceived crisis in education, fueled a conservative backlash that sought to attack any attempts at progressive education for the purpose of equity (The National Commission on Excellence in Education, 1983). Symcox (2002) writes, "Now that the neo-conservatives had established a causal relationship between the alleged educational crisis and the nation's economic decline, 'excellence' replaced 'equity' as the mantra for reform" (p. 48). In addition to "A Nation at Risk," numerous other reports flooded the public and 
political arenas that called for neoliberal practices of "teacher-proof standards, teacher-centered instruction, and authoritarian attitudes toward students" (Symcox, 2002, p. 47). However, a critical historical analysis of US education shows that if any crisis in education existed, it was in the treatment of subjugated youth of color. Since 1983, low-income youth and youth of color have borne the brunt of Draconian educational policies that have sought to reverse the clock on any progress towards equity that had been made during the post-Civil Rights era (Anyon, 1997; Noguera, 2008). Horsford (2011) documents the fact that schools are more racially and economically segregated today than after the desegregation movement ended in the 1970s. However, another consequence of the post-Reagan era, neo-conservative, and neoliberal seizure of education policy that has drastically impacted low-income youth, youth of color, and youth with histories of domestic violence is the discourse and labeling of youth as "at-risk."

Youth labeled "at-risk" are, in fact, at-risk. They are at great risk of not receiving adequate funding and resources, qualified teachers, relevant curricula, social services, and caring, empathetic, rigorous educational environments (Kozol, 2005). What has become quite apparent is that these youth are not simply at-risk, but guaranteed to be on the losing end of the educational hierarchy in the US due to the structures built into our systems to maintain social inequality. However, these are not the accepted mainstream narratives of youth at-risk. The deficit-laden language used to describe students who are at-risk serves to create a rationalization for their placement at the bottom of the educational, and then, economic and social hierarchies. These destructive discourses construct identities of resistive youth as disordered. In turn, these youth are diagnosed and deemed in need of professional or institutional intervention. As we discuss below, these interventions are costly for some institutions and equally profitable for others.

The discourse of the disordered Other categorizes the same youth who populate a bulk of K12 public school self-contained spaces, like EBD classrooms and juvenile delinquency centers. There is greater purpose to segregating these particular non-compliant youth beyond the fact that they disrupt the violent practices of public schooling; they also potentially disrupt the project of patriarchy (i.e., domestic violence as a norm), economic systems (i.e., funding for special education, accountability and efficiency agendas), the act of Othering (i.e., EBD), and the lucrative practices of incarceration (Alexander, 2012).

The discourse of the disordered Other is routinely situated in dominant discourses that conveniently and silently label resistive youth as EBD or "troubled." The "silence" refers to the euphemistic act that wipes away social and cultural experiences into "broken" individualized experiences of emotional disorders for these youth. This is an emergent form of social re-engineering (Snyder \& Mitchell, 2006) and a continuance of a compliance-oriented need to control youth who are commonly stripped of agency in the K-12 public school systems with deficit-ridden labels. Jarman, Lamp, Mitchell, Nepveux, Nowell, and Synder (2002) suggest, "institutions produce and reproduce disability as pathologised conditions and as populations in need of restrictive cultural oversight" (p. 556). The place where the deficit practices of pity and punishment intersect, both historically and in real time, are often violently shared sites of experience for youth who have come to be labeled as disordered. These deficit discourses of pity and punishment have solidified into the discursive formation of the disordered Other.

\section{Disorder as Maintenance}

What purpose do self-contained spaces like EBD classrooms or prisons serve? Schools remove and further marginalize "disordered" youth in service to "normal" youth. It is an old story — privilege 
begets privilege. Public schools work to protect "normal" (and compliant) children from their "disordered" counterparts. These acts at the local level are in service to "normal" children, families, and communities who find social comfort in the accountability and efficiency-oriented educational practices. In turn, these acts support governmental agencies in sustaining their privilege by removing, further marginalizing, and segregating "disordered" youth who choose not to comply with the masked oppressive pedagogies reflected from bureaucratic bodies and their subsequent objectives. Society claims that school spaces are "child-centered" and to keep such spaces and objects of intense interest (i.e., resistive youth) "safe," dominant thinking says these resistive youth should be placed in a self-contained space. We can now add the euphemism "safe" to a long list of marginalizing acts on the bodies of our most resistant youth. Once students are labeled and removed from mainstream educational environments, they enter into sanctioned "ghettoized" environments as described below.

This parallel educational space, replete with remedial (rote) instruction, hyper-authoritarian pedagogy, and an even greater la facultad inducing environment, serves to further entrench students in the resistant cultural practices that have, perhaps, served them well in the face of danger outside of school. Fiedler (1964) theorizes the ghettoization of marginalized communities in his assertion that "pen them off replaces kill them off as official policy (emphasis in original)" (p. 128). He goes on to write, "The ghetto has, then, two purposes: to force upon the ghetto-ized conditions of squalor which seem to verify the grounds of discrimination against them; and to make them, if not unreal, at least invisible" (p. 128). Here arises the paradox of throwaway youth. They exist in a dual reality where they are simultaneously reproduced, yet made invisible. This contradiction is at the heart of Bauman's (2009) logic that waste is inherent in all production. He writes "preferably [waste] would remain a secret. ... And yet the strategy of excess, unavoidable in a life lived-towards-a-design ... invigorates and whips up productive effort and also the output of waste, makes the cover-up a tall order" (p. 27). Bauman goes on to describe the necessity of developing waste disposal industries. While the production-line analogy of education is not new, it remains apt in describing the neoliberal standardization of education that has so effectively embedded Freire's (1970) notion of banking education in schools.

Students are still seen as empty receptacles to be filled with information, rather than cultural beings with forming ideas, philosophies, and interests. Driven by models of accountability and efficiency, students are positioned as small processing machines. They are constantly evaluated on their ability to take in (consume) information, process it, and return prescriptive answers. Students who perform this consumption well are labeled normal or useful, and students who do not-or are unwilling to-are labeled broken or what Bauman (2009) would call "flawed consumers." He writes, "consumers are the prime assets of consumer society; flawed consumers are its most irksome and costly liability" (p. 39). The cost of flawed consumers is leveraged by the capitalist machinery that finds ways to profit from waste-disposal, hence we see the emergence of the disciplinary/medicalized education market that ghetto-izes and punishes flawed consumers - throwaway youth.

\section{RESISTIVE AMBIVALENCE AS CULTURAL SURVIVAL}

Youth who have been positioned as parasites represent metaphorical resistive barometers of violent/violating acts in schools. These acts are centrally situated in both traditional and neoliberal agendas bent towards compliance, accountability, and efficiency. Subsequently, these young 
people are often diagnosed and deemed in need of professional or institutional intervention. It is overly-simplistic and a compliance-oriented act to label such perceptive people "disordered." Rather than disordered, we argue that these youth rely on resistive ambivalence or lived carnival (Bakhtin, 1981; Pyscher, 2012, 2013), described below, as sustaining acts in navigating schooling. Their cultural ways of navigating violent, yet seemingly non-violent, acts in schools are generative, liberatory-oriented positions taken up as necessary forms of cultural survival.

These resistive youth, who have been labeled disordered, perform this identity in response to the violent and discursive ways of the institutional systems and their ever-present authoritative and ideological presence. These imprisonments are materialized realities. Resistively ambivalent acts performed by these youth can be described as a defense against a variety of authoritative practices. Fine (1994) helps to describe the power of these practices "as largely invisible to common sense ways of making meaning" (p. 25). We evoke Bakhtin's concept of carnival to explain the resistant ambivalence performed by youth in the face of school-based oppressive practices.

A fundamental part of Bakhtin's (1981) concept of carnival is resistance. The grotesque body and its expulsion of hierarchical actions often symbolize this particular resistance. As an extension, Elliot (1999) argues, "Carnival shakes up the authoritative version of language and values, making room for a multiplicity of voices and meanings" (p. 129). Both resistive adults and youth with racialized and/or histories of domestic violence tend to be the very subjects that the dominant institutional structures and the more privileged individuals/communities never want to become. Stamm (1982) argues, "Carnival in this sense implies an attitude of creative disrespect, a radical opposition to the illegitimately powerful, to the morose and monological" (p. 55). Equally, these structures and the folks who practice within them (e.g., teachers, administrators, social workers) often refuse to recognize their culpability in the very construction and the creation of the violent Other rather than employing a loving gaze. Resistive youth examine life in response to what Foucault (1973) calls the medicalized gaze. There is a dramatic shaping affect of such a gaze for youth who resist socioculturally violent/violating practices. The gaze is euphemized in terms like "disordered," and subsequently, these "broken" youth are in need of specialized treatment by various types of educational and psychological professionals. When one's omnipresent imprisonment is so thoroughly solidified through every institutional turn, liberation through resistive ambivalence becomes a necessitated lived experience or lived carnival (Pyscher, 2012). Resistive ambivalence can be described as lived liberatory actions in the face of violent authoritative practices. Importantly, Bauman (2009) argues that when one is deemed "wasted," immeasurable power can be produced through acts of ambivalence. He describes waste as endowed with an "awesome, truly magic power, equivalent to that of the alchemists' philosopher's stone - the power of a wondrous transmutation of base, paltry and menial stuff into a noble, beautiful and precious object" (Bauman, p. 22). Further, he describes waste as "an embodiment of ambivalence.... Waste is sublime: a unique blend of attraction and repulsion arousing an equally unique mixture of awe and fear" (p. 22). Embodied in the agentic acts of youth performing lived carnival is the transformative potential to disrupt the school-to-prison pipeline when educators come to see these youths' resistance not as "disorder," but as resistive ambivalence-liberatory cultural ways of navigation from which we can all learn. Understanding resistive ambivalence opens possibilities for a different set of pedagogies and ways of being in relationship with youth who have intimate relationships with, and have developed cultural repertoires situated in, cultural and social violences. Equally, understanding resistive ambivalence offers educational staff the ability 
to trace how their seemingly non-violent practices actually create violent/violating experiences for many youth.

When youth enact resistive ambivalence, they can evoke Bauman's (2009) notion of mysterious, awe-inspiring fear. Equally, like the proverbial brick wall, these states of ambivalence run smack into ever-present compliance-oriented pedagogies. Teachers typically depend on compliance manifested through pedagogy. Classroom management has become synonymous with teaching (Casey, Lozenski, \& McManimon, 2013). Thus, teachers need all youth to be compliant, follow the rules, and sit through seemingly innocent acts of accountability and responsibility. In the face of even small acts of pedagogical violence, resistively ambivalent youth will mostly never negotiate this shared space with educators. It is a no-win situation when teachers try to force these youth to comply through violent/violating acts such as being socially shamed or through low expectations expressed in verbal/non-verbal cues. For such youth, the fall back will almost always be resistive ambivalence.

\title{
Habitus and Resistive Ambivalence as Cultural Repertoire
}

\author{
"As opposed to the official feast, one might say that carnival celebrates temporary liberation from the \\ prevailing truth of the established order; it marks the suspension of all hierarchical rank, privileges, \\ norms and prohibitions."
}

-Bakhtin, 1965, p. 7

How might resistive ambivalence be iterated through embodied knowledge? This way of being in the world is captured in Bourdieu's (1997) notion of habitus, defined by Vadeboncoeur (2005) as "a collection of dispositions that are inscribed on and lived through the body ... through disposition, people evaluate and judge the value of the social languages of others and, in doing so, they may recognize, re/produce or resist dominant ... linguistic or symbolic capital" (p. 128). We argue that if one's habitus is constructed from sociocultural violence, then resistive ambivalence, in turn, can be a common lived practice; resistance strategically becomes an embodied ambivalence (Pyscher, 2012). Resistively ambivalent youth contest the masks of hypocritical social and cultural farce and pretense. Bakhtin (1981) argues the people of carnival see the underside and falseness of every situation" (p. 159). There is a visceral and discomforting way of being in the world for youth whose habitus is constructed through domestic violence and historical racialized violence, which, in turn, challenge sociocultural violences. In the words of Bakhtin (1981), one has "the right to be 'other' in this world, the right not to make common cause with any single one of the existing categories that life makes available" (p. 159). The social experiences of resistive youth can be defined by a sorrowful, transformative, and ongoing resistive ambivalence serving as a barometer of institutional violence that is then embodied in all subsequent speech and bodily acts. Gutierrez and Rogoff (2003) suggest that, over time, children develop repertoires of practice that they are able to draw from in situated moments. These repertoires come from their historical, individual, and communal interactions with their sociocultural worlds, through which they make cultural meaning. Gutierrez and Rogoff suggest that in order to understand the cultural repertoires of a child, one must know their individual and community history. Resistive ambivalent youth, who come from historically racialized places or have histories of domestic violence, have developed their own liberatory-oriented repertoires of practice that have often proven successful in the face 
of socioculturally violent conditions. For these youth, exercising resistive repertoires of practice, often under harsh conditions, are liberatory acts. We believe educators need to redeploy similar agentic and transformative acts in their relationships and interactions with resistively ambivalent youth.

\section{CONCLUSION: THE GENERATIVE USE OF LA FACULTAD}

We do not contend that our teaching colleagues intend to do harm. Rather, we offer an analysis that names and potentially liberates us all from the shaping effects of dominant discourses (e.g., neoliberal agendas, medicalized models of deficit). In order to make liberatory sense of these discourses, we must take up the challenge to look upon our fractured selves and the youth we work with as situated in sociocultural experiences. This is not an argument to eliminate any and all behavioral expectations in schools, but rather to recognize that resistive acts can point us toward violent pedagogical practices. Incorporating these sensibilities into our cultural repertoires allows us to transcend and move towards Anzaldúa's (1987) freeing notion of la facultad.

La facultad is somewhat esoteric due to its emphasis on both the lived experience and a deeper spiritual existence that has been contested and suppressed by Western philosophies and hyper-rationality. As Anzaldúa (1987) guides us through the layers of la facultad, she appears to create a distinction in the way she accounts for its latency and the mechanisms through which it can be realized. La facultad is initially described as an ultra-perception; a characteristic of hyperawareness about surroundings possessed (knowingly and unknowingly) by people who have been oppressed, or who live alongside the threat of perpetual violence. For this population, la facultad is positioned as a necessary survival mechanism that is cultivated and nurtured through fear. For educators whose habitus is not constructed through historical and lived domestic violence, Anzaldúa goes on to develop what she describes as "a deeper sensing that is another aspect of la facultad" (p. 61). This deeper aspect is realized through experiences that disrupt one's sense of psychological comfort, forcing us to question and reshape core beliefs and possibly our core sense of self. Anzaldúa appears to be opening a space for everyone - not only the oppressed - to potentially discover and develop this capacity by "confronting anything that tears the fabric of our everyday mode of consciousness and that thrusts us into a less literal and more psychic sense of reality" (p. 61). For educators in classroom spaces this could mean something as simple as studying the cultural repertoires of youth performing resistive ambivalence. Gutierrez and Rogoff (2003) suggest that these repertoires include "engaging in discussions with authority figures, answering known-answer questions, analyzing word problems on the basis of counterfactual premises, seeking or avoiding being singled out for praise" (p. 22) among others. However, if we are to take Bauman (2009) and Anzaldúa's (1987) critique seriously, we must recognize how our ideologies and practices often compete against our own humanity. It is the responsibility of educators, not students, to create the conditions that are adaptive and dynamic and allow for a protean existence to emerge.

Within this Western world, some people exist in multiple realities-the world of imagination and spirit, and the world of consciousness and rationality. Those who are able to exist in and between these worlds have developed la facultad. This space between worlds is an example of the many Borderlands that Anzaldúa names. This particular Borderland of la facultad, however, is more elusive than those of language, political geography, gender, sexuality, race, or experiences 
of domestic violence. This internal Borderland exists within the body and the mind, thus it encompasses all of the other Borderlands that Anzaldúa describes. This Borderland is one of conscious and psyche, it pits the socially constructed physical realm and the psychic/spiritual realm as opposing forces contesting for control of reality.

For resistive youth, la facultad is a way of being in the world. They exist always on guard, always ready to protect themselves if necessary. Duncan-Andrade (2011) suggests that if we do nothing, some "roses will continue to grow through the concrete" in spite of us. Resistively ambivalent youth have been growing and blossoming in spite of us. They find ways to live, breathe, love, and be more fully human despite the ways we condemn them. It is imperative that educators begin to understand that resistive youth are not behaviorally deficient; rather their actions are identifying moments for deep personal and pedagogical introspection. These youth are demanding that we "[confront] anything that tears the fabric of our everyday mode of consciousness" (Anzaldúa, 1987, p. 61), so as to get beyond our own rationalizations for systemic reproduction of "throwaway youth."

\section{NOTE}

1. Our purpose in using the adjective "unintentional" is to demonstrate our solidarity with educators. As educators ourselves, with over two decades of combined teaching experience, we believe that teachers, overwhelmingly, do not intend to enact violent or violating practices. However, we also recognize the structural conditions with which teachers must contend, that do result in the violent and violating outcomes that many youth experience. Our work is about being in solidarity with both youth and educators, which often places us in a contradictory space.

\section{REFERENCES}

Alexander, M. (2012). The new Jim Crow: Mass incarceration is the age of colorblindness. New York: New Press.

American Academy of Experts in Traumatic Stress (AAETS). (n.d.). Long-term consequences of child abuse and neglect: Child welfare information gateway. The American Academy of Experts in Traumatic Stress. Retrieved from $\mathrm{http}: / /$ www.aaets.org/article185.htm

Anderson, J. (1988). The education of blacks in the South, 1860-1935. Chapel Hill, NC: University of North Carolina Press.

Anyon, J. (1997). Ghetto schooling: A political economy of urban educational reform. New York: Teachers College Press. Anzaldúa, G. (1987). Borderlands: The new Mestiza = La frontera. San Francisco, CA: Aunt Lute.

Bakhtin, M. M. (1965). Rabelais and his world (Helene Iswolsky, Trans.). Bloomington, IN: Indiana University Press.

Bakhtin, M. M. (1981). The dialogic imagination: Four essays (C. Emerson \& M. Holquist, Trans.). Austin, TX: University of Texas Press.

Bauman, Z. (2009). Wasted lives: Modernity and its outcasts. Cambridge, UK: Polity.

Black, M. C., Basile, K. C., Breiding, M. J., Smith, S. G., Walters, M. L., Merrick, M. T., \& Stevens, M. R. (2011). National intimate partner and sexual violence survey. Atlanta, GA: Centers for Disease Control and Prevention.

Bourdieu, P. (1997). Pascalian meditations. Stanford, CA: Stanford University Press.

Bowles, S., \& Gintis, H. (1976). Schooling in capitalist America: Educational reform and the contradictions of economic life. New York, NY: Basic.

Carter, P. (2005). Keepin' it real: School success beyond black and white. New York, NY: Oxford University Press.

Casey, Z. A., Lozenski, B. D., \& McManimon, S. K. (2013). Neoliberal teachers, neoliberal pedagogy: Racializing and historicizing classroom management. Journal of Pedagogy, 4(1), 36-58. 


\section{PYSCHER AND LOZENSKI}

Child Welfare Information Gateway. (2006). Long-term consequences of child abuse and neglect. Washington, DC: US Department of Health and Human Services. Retrieved from http://www.childwelfare.gov/pubs/factsheets/long_term_ consequences.cfm

Counts, G. (1932). Dare the school build a new social order? London, UK: Southern Illinois University Press.

Dewey, J. P. (1997). Alaskan female inmate survey. Unpublished Master of Social Work thesis, University of Alaska Anchorage.

Duncan-Andrade, J. (2011). TEDx Golden GateED, “Growing roses in concrete.” Retrieved from http://www.youtube. $\mathrm{com} / \mathrm{watch} ? \mathrm{v}=2 \mathrm{CwS} 60 \mathrm{ykM} 8 \mathrm{~s}$

Duncan-Andrade, J., \& Morrell, E. (2008). The art of critical pedagogy: Possibilities for moving from theory to practice in urban schools. New York, NY: Peter Lang Publishing.

Elliot, S. (1999). Carnival and dialogue in Bakhtin's poetics of folklore. Folklore Forum, 30, 129-139.

Fiedler, L. (1964). Waiting for the end. New York, NY: Stein \& Day.

Fine, M. (1994). Dis-stance and other stances: Negotiations of power inside feminist research. In A. Gitlin (Ed.), Power and method: Political activism and educational research (pp. 13-34). London, England: Routledge.

Fine, M., \& Ruglis, J. (2009). Circuits and consequences of dispossession: The racialized realignment of the public sphere for U.S. youth. Transforming Anthropology, 17(1), 20-33.

Fletcher, M. (2008). American Indian education: Counternarratives in racism, struggle, and the law. New York, NY: Routledge.

Fordham, S., \& Ogbu, J. (1986). Black students' school success: Coping with the "burden of 'acting white." Urban Review, 18, 176-206.

Foucault, M. (1973). Birth of the clinic: Archaeology of medical perception. New York, NY: Vintage.

Freire, P. (1970). Pedagogy of the oppressed. New York, NY: Continuum International.

Giroux, H. (2001). Theory and resistance in education: Towards a pedagogy for the opposition (revised and expanded ed.) Westport, CT: Greenwood.

Grande, S. (2004). Red pedagogy: Native American social and political thought. Lanham, MD: Rowman \& Littlefield.

Gutierrez, K., \& Rogoff, B. (2003). Cultural ways of learning: Individual traits or repertoires of practice. Educational Researcher, 32(5), 19-25.

Harvey, D. (2005). A brief history of neoliberalism. New York, NY: Oxford University Press.

Horsford, S. D. (2011). Learning in a burning house: Educational inequality, ideology, and (dis)integration. New York, NY: Teachers College Press.

Jarman, S. L., Mitchell, D., Nepveux, D., Nowell, N., \& Synder, S. (2002). Theorising disability as political subjectivity: Work by the UIC disability collective on political subjectivities. Disability \& Society, 17(5), 555-569.

Kim, C., Losen, D., \& Hewitt, D. (2010). The school-to-prison pipeline: Structuring legal reform. New York, NY: New York University Press.

Kozol, J. (2005). The shame of a nation: The restoration of apartheid schooling in America. New York, NY: Three Rivers.

Lewis, C., Enciso, P., \& Moje, E. (Eds.). (2007). Reframing sociocultural research on literacy: Identity, agency, and power. New York, NY: Routledge.

McKenzie, K. (2009). Emotional abuse of students of color: The hidden inhumanity in our schools. International Journal of Qualitative Studies in Education, 22(2), 129-143.

Messina, N., \& Grella, C. (2006). Childhood trauma and women's health outcomes in a California prison population. American Journal of Public Health, 96(10), 1842-1848.

Minnesota Indian Women's Sexual Assault Coalition. (2009). Retrieved from http://www.miwsac.org/index.php?option= com_content\&view $=$ article\&id $=96 \&$ Itemid $=195$

The National Commission on Excellence in Education. (1983, April 26). A nation at risk: The imperative for educational reform. Letter to Honorable T. H. Bell Secretary of Education U.S. Department of Education. U.S. Department of Education. Washington, DC: U.S. Government Printing Office.

Noguera, P. (2008). The trouble with black boys ... And other reflections on race, equity, and the future of public education. San Francisco, CA: Jossey-Bass.

Pratt, R. P. (1973). "The advantages of mingling Indians with whites": Americanizing the American Indians: Writings by the "friends of the Indian" 1880-1900. Cambridge, MA: Reprinted in Harvard University Press, pp. 260-271. Official Report of the Nineteenth Annual Conference of Charities and Correction (1892), pp. 46-59.

Pyscher, T. (2012, April). Lived carnival, habitus, and resistance: A childhood forged through violence. Paper presented at the American Education Research Association, Annual Conference, April 13-17, Vancouver, BC. 
Pyscher, T. (2013, May). Rubbish collecting: When educators meet resistive ambivalence. Paper presented at the American Education Research Association Annual Conference, April 27-May 1, San Francisco, CA.

Roberts, D. (2011). Fatal invention: How science, politics, and big business re-create race in the twenty-first century. New York, NY: The New Press.

Sleeter, C. (1987). Why is there learning disabilities? A critical analysis of the birth of the field in its social context. In T. S. Popkewitz (Ed.), The formation of school subjects: The struggle for creating an American institution (pp. 210-237). New York, NY: Falmer.

Snyder, S. L., \& Mitchell, D. T. (2006). Cultural locations of disability. London, UK: Chicago University Press.

Sotero, M. (2006). A conceptual model of historical trauma: Implications for public health practice and research. Journal of Health Disparities Research and Practice, 1(1), 93-108.

Stamm, R. (1982). On the carnivalesque. Wedge, 1, 47-55.

Symcox, L. (2002). Whose history? The struggle for national standards in American classrooms. New York, NY Teachers College Press.

Tuck, E. (2009). Suspending damage: A letter to communities. Harvard Educational Review. 79(3), 409-427.

Tuck, E., \& Yang, K. W. (2012). Decolonization is not a metaphor. Decolonization: Indigeneity, Education \& Society. 1(1), 1-40. http://decolonization.org/index.php/des/article/view/18630/15554

Tuck, E., \& Yang, K. W. (2014). Youth resistance research and theories of change. New York, NY: Routledge.

Vadeboncoeur, J. A. (2005). The difference that time and space make: An analysis of institutional and narrative landscapes. In J. Vadeboncoeur \& L. Patel Stevens (Eds.), Re/constructing "the adolescent": Sign, symbol, and the body. New York, NY: Peter Lang.

Vadeboncoeur, J., \& Luke, A. (2004). Who's/whose at risk? Answerability and the critical possibilities of classroom discourse. Critical Discourse Studies, 1(2), 201-223.

Waitoller, F., Artiles, A., \& Cheney, D. (2010). The miner's canary: A review of overrepresentation research and explanations. The Journal of Special Education, 44(1), 29-49.

Willis, P. (1977). Learning to labor: How working class kids get working class jobs. New York, NY: Columbia University Press.

Woodson, C. (1933/1990). The mis-education of the negro. Trenton, NJ: Africa World Press.

Tracey Pyscher is a PhD candidate in literacy education within the Department of Curriculum $\&$ Instruction at the University of Minnesota. Her research focuses on critical literacy and how youth with histories of domestic violence experience and navigate public schooling.

Brian D. Lozenski is an assistant professor in Metropolitan State University's School of Urban Education. His research focuses on critical participatory action research with youth of African descent. His work is engaged with various communities in the Twin Cities that are fighting for justice through education. 